\title{
Comprehensive Scrutiny on the Concept of Group Work for English Language Teaching
}

\author{
Mr. Muluken Gebre Lanka (Principal Author) \\ Department of English Language and Literature, Wolaita Sodo University, Ethiopia \\ Fikre Tadese Demise (Co-Author) \\ Department of English Language and Literature, Wolaita Sodo University, Ethiopia
}

\begin{abstract}
Prologue
In this literary review the researchers presented the concept of group work, types of group work, group work activities, forming and organizing groups, advantages and disadvantages of group work, the impact of teachers' and students' attitude towards group work activities, the teachers and students role in group work activity, factors affecting the implementation of group work activities in English language teaching (hereinafter referred as "ELT"). And also the concept of speaking, group work activities used to teach speaking and functions of speaking in group work. The reader/learner will be benefitted from the article.
\end{abstract}

DOI: $10.7176 / \mathrm{JEP} / 11-28-01$

Publication date:October $31^{\text {st }} 2020$

\section{The Concept of Group Work}

One of the most important strategies of learning and strengthening students' interaction is the group work. Different scholars define it from different perspectives. For example, Adams and Hamm (1990) defined group work as a form of cooperative learning in that several people work together to finish a certain task or achieve a certain learning goal. According to Hansen (2006), group work is one of the teaching learning strategy to improve our learning and overall skills. It is the way to develop students' integrated skill by engaging them in group. Scrivener (2011) argues that group work is a learning strategy which allows students to develop their critical skills and helps them to challenge assumptions. He further states that this type of learning strategy helps students to evaluate their works and ideas thus they learn from each other. This indicates that it is an approach that makes students independent and helps each other.

Konopka (1963) defined group work as a method of social work that is utilized in order to 'help individuals to enhance their social functioning through purposeful group experiences, and to cope more effectively with their personal, group or community problems. Burdett and Hastie (2009) noted that group work is a technique followed to provide an opportunity for students to engage in peer to peer learning. It gives chance to students to use the target language for communication rather than to practice it in situations to control students. These conditions are realized if students are put in-group activities. Furthermore, Badache (2011) defines group work as an instruction method where learners of different levels form small groups and work together towards a specific objective. Learners take the responsibility of their own learning and of those in the group, so the success of one member is a success of all members. Forsyth (2006) stated that group work enables students to move more readily from receiving knowledge to generating knowledge which involves students working collaboratively on set tasks, in or out of the classroom, includes any learning and teaching tasks or activities that require students to work in groups and any formal assessment tasks that require students to work in groups.

Brown (1994:8) provides a comprehensive definition of group work; he states that it provides a context in which individuals help each other. It is a method of helping groups as well as helping individuals; it can enable individuals and groups to influence and change personal, group and community problems. group work has been described as a valuable instructional approach which facilitates the learning process, provides opportunities for learners to explore the new content, creates positive interaction, process information, obtain new knowledge and skills, increase motivation, confidence in one's social skills and academic achievement.

According to Brown (1991) group work is defined as a generic term covering a multiplicity of techniques in which two or more students are assigned a task that involves a cooperative work. He has also shown the significance of cooperation among members to deal with the given activity. Simply a collection of individuals sitting together without any coordination and common objectives may not mean group work. In order to say the collection of individuals group work learning, there must be a link among all group members that shows cooperation and collaboration to achieve a common goal of their learning.

Moreover, group work is a small discussion which has its own purpose, ideal for helping students to make meaning, take responsibility for learning, and practice effective strategies (Spiegel, 2005). When students work alone, of course they can make meaning. But group discussion provides opportunities for reflection and revision of meaning, opportunities that are less likely to occur when working alone. Furthermore, sharing their thoughts forces students to be explicit in their thinking, so they can present their ideas clearly. While the discussion is on, 
listening to the meaning others construct may lead to conflict from which new ideas may emerge. Group discussion has fewer participants than whole class discussion and the quality of interaction is likely to be better and more suitable for making meaning (Davies, 1994). Individual voices are tend to be heard because it is easier to hear and hard to avoid paying attention.

\section{Types of Group Work}

Scholars classified the types of group work in three forms. They are collaborative, pair work and cooperative learning. Collaborative learning is a teaching and learning strategy that can be utilized for students and can take various forms in the classroom. In collaborative group work, every group member is involved in working on a given task to produce an outcome that they all agree upon (Chiriac and Frykedal, 2011). This allows English language learners, the opportunity to be in an environment where they can work together to discuss their ideas, share and listen to their peers' thinking process. Nair and Alwee (2012) state that opportunities are provided through group work for students to talk freely with their peers, which ultimately allow all students to practice and improve their oral language skills.

Another form of group work only involving two participants is pair work. This type of group work fosters two students to communicate with each other as they teach and learn from each other. To enhance language skills, students need opportunities to practice with their peers. Through pair work, students are able to share in more talking time to freely communicate in the classroom (Nair and Alwee, 2012). It enables learners to express their ideas without any fear in the classroom as well as outside the classroom. Tuan and Nhu (2010) argue that students can practice their oral language skills more efficiently in pair than in a whole-class setting.

Creating a more intimate and relaxed environment, two students working together in a group has more benefits than allowing the whole class to participate in a discussion. This helps students articulate their thinking with a peer partner before having to contribute in the large group, and works well in encouraging those reluctant learners to rehearse before speaking (Swain, 1980).

Another form of group work is cooperative learning. Kutnick et al. (2006) said that cooperative learning is more effective for students to share their cognitive, perspective and problem-solving skills than students working individually. However, cooperative learning is different from collaborative learning because it must include, and students need to demonstrate five specific principles for cooperative group work to be successful (Gillies, 2003).

According to him in structuring cooperative learning, it must include five key elements. They are positive interdependence, accountability, social and cognitive development and interaction. Cooperative learning is an effective way to encourage students to learn more effective social skills (Johnson and Johnson, 1991:15). In cooperative learning groups, each student has a specific role and students are able to produce work based on everyone's input. Therefore, cooperative learning is an essential strategy for supporting in the classroom.

Positive interdependence: this point of group work shows that each group member depends on each other to accomplish a shared goal or task. Students consider the needs of other students with in groups to encourage and participate in the learning process all the time because without the help of one member the group is not able to reach the desired goal. According to Johnson and Johnson (1991) Students must believe that they are linked with others in a way that one cannot succeed unless the other members of the group succeed and vice versa. Students will also care about and get committed to each others' success as well as their own when they understand the goal, task, and resource and role interdependence. Furthermore, one member in a group will not give less value to other member's efforts when there is well structured reward interdependence that treats all members equally in a group.

Face-to-face interaction: this has a vital role in promoting success of group members by praising, encouraging, supporting, or assisting each other. This indicates that in the context of group work, students interact to help each other accomplish the task and promote each other's success. Students are expected to explain orally to each other how to solve problems, discuss with each other the nature of the concepts and strategies being learned, teach their knowledge to classmates, explain to each other the connections between present and past learning, and help, encourage, and support each other's efforts to learn (Harmer, 1999). The teacher help to guide the students, manage their activities, and direct their learning. Teachers are also expected to structure the groups so that students seat together and discuss through each aspect of the task given.

Individual accountability: each group member is held responsible for his or her work. Students learn together so that they can subsequently perform better as individuals. To ensure that each member is strengthened, students are held individually accountable to do their share of the work. According to Brumfit (1994) the performance of each individual student is assessed and the results given back to the individual and perhaps to the group. The group needs to know who needs more assistance in completing the assignment, and group members need to know they cannot get a ride on the work of others. Therefore, a level of accountability or responsibility must be structured into cooperative activities so as to help learners subsequently gain greater individual competence.

Social skills: group works set the stage for students to learn social skills. These skills help to build stronger cooperation among group members. Students must have and use the needed leadership, administrative, trustbuilding, announcement, and conflict-management skills. These skills have to be taught just as purposefully and 
precisely as academic skills. Many students have never worked cooperatively in learning situations and, therefore, lack the needed social skills for doing so effectively. Thus, social skills are strong keystones for building and maintaining a stable family for a successful occupation, and for a stable group of friends.

Group processing: group processing is an activity of how groups are functioning to achieve their goals or tasks. By reviewing group behavior the students and the teacher get a chance to discuss special needs or problems within the group. Groups get a chance to express their feelings about beneficial and unhelpful aspects of the group learning process in order to correct unwanted behavior and celebrate successful outcomes in the group work. Continuous development of the process of learning results from the careful analysis of how members are working together and determining how group effectiveness can be improved.

\section{Group Work Activities}

Group work activities are one of the important class activities for developing students' communicative ability. It refers to any classroom activity in which the whole class is divided up into pairs or larger groups. It is a form of activities that it is organizing them in order to encourage collaboration among students. They increase the opportunities for social contact among students which are linked to student satisfaction, retention and enjoyment of study, and they can have a motivational effect as students do not wish to let down other members of their group (Bloxham and Heath field, 1994).

There is some evidence that group work activities improve the achievement of lower ability students on subsequent assignments although the reverse was found for higher ability students (Lejk et al., 1999). However, group work assignments do present potential problems if not handled or organized well and it is recommended that there should be a limit on the number in any student programmed (Falchikou, 2005). The existence of well organized group work activities in the classroom can create good understanding between students and encouraging student centered confidential atmosphere.

According to Cohen (1994) group work activity is said to include higher order thinking, better communication, conflict management, greater understanding and development of skills transferable to later work environments. Doing group work activities may be a very common activity to every student during the academic year. To handle the activities, students choose to corporate with others and work in groups. Working with group consequently helps students improve their teamwork skill, in addition to critical thinking and confidence that are gained during discussions. Groups surely need to divide the task into smaller parts, and as each student handle part they find suitable most, the task can be done really effectively.

Group work is a form of cooperative learning. For many years, in secondary school have been grouping students together to work on specific assignment. In the recent years, the investigation of group work is becoming more popular in education. Engaging students with group learning activities can benefit them with high quality learning outcomes and satisfaction, if teachers are assessed with valid and fair grading which is able to reliably reflect the contribution of individual students and students are efficiently managed in group to work together.

However, if students are not clear about the objectives and expectations of the group work, or are questioning the validity and fairness of the assessment, it may cause confusion and competition among the group. And the educational benefit of group work is less effective.

\section{Forming and Organizing Groups}

In the English language teaching and learning, where students have most often been rewarded for individual effort, groups may not come naturally or easily for everyone. And even though, most students have worked together informally in study groups or social organizations, they may never have thought carefully about the kinds of skills that best promote group achievement. Most faculty who have included collaborative work in their courses agree that groups of between 4 and 6 students seem to work best, though depending on the task, larger groups eight to ten students can function successfully.

Harmer (2003) stated that determining how the groups will be formed can be more complicated, since ideally the groups should be diverse enough to include students with a range of intellectual abilities, academic interests, and cognitive styles. Allowing students to select their own group members can work well in small classes, but this method always runs the risk of further isolating some students the class as a whole.

However, some of the most important aspect that EFL classroom teachers need to consider is the size of each group. The choice of group size for English language practice actively will depend largely on the size of the class and the aim and the type of activity in question. Some scholars believe that the size of the group should be decided on the basis of students' experience and the time given for the effectiveness of cooperative learning. According to Harmer (1991), it has been believed that the optimum number of students assigned to groups should not exceed three to seven students.

Lotan (2004) stated that group size should be in small number not greater than six students because as group size increases, individual motivation decreases. Four to eight students in each group is an acceptable size, although there is no one and clear group size (Byrne, 1987). This indicates that groups with smaller number of students are 
better for some activities, but group with larger number may be also better if the teacher needs students to share ideas and experiences with their group members. Organizing groups are the aspects when forming groups in the process of English language teaching and learning. In order to assign students to groups, English teachers may take different positions because of the differences that exist among the students.

Different scholars have different views of organizing groups. For instance, Callahan and Clark (1988:159) stated that groups should probably be based on interest or perhaps specific skills, rather than on students' general ability. Another way, Johnson and Johnson (1990:123) propose random assignment of students to groups as an effective way. Unless special attention should be given, the intended objective in giving assignments can't be achieved. Therefore, various ways of assigning students to groups, we see that some may tend to group students in terms of their ability as heterogeneous or homogeneous learning groups; some other may prefer random, interest, age, achievement, friendship or convenience grouping technique depending on the purpose and the type of the task.

According to Borich (2007) groups should be allowed to choose their leaders for effective and orderly interaction in group activities. Group leaders can be appointed by the teacher or nominated by groups. They should be well organized and have made time in their lives for their organization because they have significant roles in group activities. Group leaders act as facilitators by coordinating the efforts of group members towards a successful completion of an assignment. And teachers are grand group leaders who are accountable for the success or the failure of the class as a group. Besides, it encourages learners to feel responsibility for their own learning.

\section{Advantages of Group Work in Speaking Classroom}

According to Long and Porter (1985) the use of group work in classroom has long been supported to teachers for a number of years because of its perceived benefits to language learners. Brumfit (1984) stated that group work is seen as an essential element communicative language teaching in that it offers opportunities for cooperative learning and real language practice with consequent gains in language proficiency. In addition, group work provides a less threatening situation to the individual learners, who can experience lower levels of anxiety in the classroom when practicing language with sympathetic peers.

According to Exley and Dennick (2004:4-5) have listed out of the following points which are the aim of engaging students in group activities. First, the development of intellectual understanding and of intellectual and professional abilities: by thinking and problem solving, e.g. analyzing, evaluating evidence, logical reasoning and synthesizing, by clarifying concepts and theories through discussing and accepting and seeing interrelationships and connections. Second, the development of communication skills and of group work skills: working in a group gives an opportunity to practice a variety of group management skills and group roles including leadership, planning and organization, giving support and encouragement to others, setting tasks, monitoring progress.

Through discussion practicing, giving explanations, listening, questioning, presenting, defending a position and giving constructive feedback are obtained. Third, personal growth and support for interdependence: by taking part in debate and discussion, students can test their values and attitudes while developing self esteem and confidence and by preparing for and taking part in small group teaching discussions and activities students accept their personal responsibility for the progress and direction of their own learning.

Finally, by reviewing and reflecting on their actions, students can learn from their successes and failures, so develop their skills and understanding, and plan future learning. It is important to analyze why EFL teachers use group work in speaking classroom. The researcher personally considers that group work is not just time-filler, or thoughtless activities that EFL teachers sometimes use for checking group work activities. Group work should not be used as class time for teachers to read, to rest. To prepare other classes, or just to imitate other teachers that are using group work without really understanding what that is and entails. The real purpose of working in groups in an EFL class goes beyond the actual command: "Get in a group, please, and answer the following questions," which in most of the case, turns out to be individual work

According to Harmer (2003) there have been many discussions on the value of group work for language learning which have confirmed that the advantages of group work. Group work gives students more chance to interact and use the target language more freely. Instead of just having a few seconds to talk in teacher-fronted classes, students can participate longer in small group and feel more confident to give their options and even make mistakes when just three or four classmates are looking at them.

Brown (2001) states that "small groups provide opportunities for students to initiate themselves, to encourage face-to-face interaction, to practice negotiation of meaning, to extend conversational exchanges, and to students' adoption of roles, that would otherwise be impossible. Therefore using group work substantially increases the opportunities which students get to speak English. Group work creates a positive atmosphere in the sense that some students will not feel vulnerable to public display that may cause rejection or criticism (Porter, 1985). It is totally true that shy or low risk-taker students feel much more confident working in small groups than in teacherfronted classes. They also said that when mutual goals are established, and ideas, material and information are shared, a collaborative partnership also develops in which students learn how to learn with one another. Students can develop social skills which were normally practiced only by the teacher such as changing topic, turn-taking, 
asking for clarification and so on, appropriate materials to work on and problems to solve, students can engage in genuine information exchange.

Learner's responsibility give and autonomy are encouraged through group work. "The small group becomes a community of learners cooperating with each other in pursuit of common goals" (Brown, 2001:178). Students are not constantly relying on the teacher to complete their tasks. They learn that they can complete an activity successfully with the help of other classmates or by themselves. Students can be more autonomous and self reliant; they can take on roles and adopt positions which are usually the teacher's preserve. So that they can practice a range of language functions associated with those roles and positions, e.g. in problem solving exercises, they can learn to suggest, infer, qualify, hypothesize, generalize, or disagree.

Group work encourages students to become more engaged in material through discussion, debate, and the opportunity to articulate explanations to their peers (Swain, 1985). Such classroom practices allow students to check their understanding and construct new knowledge through interactions with each other and with course material which are the most important aspects for meaningful learning.

By using group work the teacher has the opportunity to teach turn taking mechanisms. As Kramsch (1992) suggests that teaching students how to take turns, as easy as this might seem, requires teaching a number of skills that are not automatically transferred from the mother tongue such as to tolerate silences, to direct gaze to addressees, to make use of floor-taking gambits, and to take long turns.

\section{Disadvantages of Group Work in Speaking Classroom}

Group work has also disadvantages that are important to explore. The first problem relates to noise. Obviously, students speak all at once trying to accomplish their task, and this causes noise that may bother other colleagues. But Doff (1991:141) states that the noise created by group work is usually good, noise since students are using English and are engaged in learning task. What a teacher can do to solve the "noise problem" is to make students aware that they do not need to shout to be heard and this will help to keep noise at moderate level. Another negative aspect of group work is the fact that some teachers may lose control of the class or have difficulties controlling the class, especially what concerns to discipline.

However, even if students are working in small groups and are in charge of the completion of a task, the teacher is still the director and manager of the class and needs to make students aware of this. Doff (1991:142) highlights that in order "to stop activities setting out of control, it is important to give clear instructions, to give clear defined tasks and to get up a routine so that the students exactly know how and what to do". If the teacher circulates around the class to clarify doubts and to monitor what students are doing, there is no reason for losing control of the class.

The use of native language and lack of correction of mistakes represent another dislikable future of group work. This is true even in teacher-centered classes. Students make use of any opportunity to switch to their native language. To avoid this, Brown (2001:180) suggests "encouraging students to practice using the target language in face-to-face contexts and to make them aware of the importance of some real uses for English in their own lives". When working in groups, students are surely going to make mistakes. But Brown (2001:181) states errors are a necessary manifestation of inter language development, and we do well not to become obsessed with their constant correction. Well managed group work can encourage spontaneous peer feedback on errors within the small group itself.

In-group work activities one or two of the group members may force the passive learners to accept their ideas. This means some students are active participants than the others and these higher able students dominate the less able once. Regarding this idea, Arends (1997:135) stated that during cooperative learning, some students dominate group activity; others may be unwilling to participate. Sometimes those who avoid group work are shy students. Shy students are often very bright and they may work well alone or with one another. However, they find it very difficult to participate in a group. The rejected student is another type of student who may have difficulty to participate in-group activity. Finally, there is otherwise typical student who chooses for what every reason to work alone refuses to participate in cooperative group endeavors.

Cohen (1994) stated that students with high academic status are commonly believed by their teachers to do better in-group activity than those with low academic status. These make academically able students dominate the group alone. Regarding this, Cohen (1994:154) stated that high status students are generally expected to do well on new intellectual tasks, and low status students are generally expected to do poorly on the same task. When a teacher assigns a group work task, general expectations some into play and produce a self - fulfilling prophecy in which the high status students talk more and become more influential than the low status students.

In addition, Johnson and Johnson, (1989) states that there are several ways in which group efforts go wrong. They further go that less able students sometimes leave group's task to others to be completed. Thus, the able members become 'free riders' of doing the majority of group activity. Regarding this, Waxman and Walberg, (1991:275) stated that in group learning high ability group members may be differed to and may make over the important leader ship roles in ways that benefit them at the expense of the other group members ('the rich-get- 
rich effect'). The more able group members may give all the explanations what is to be learned. Since the amount of time spent explaining correlations highly with the amount of learned, the more able members learn a great deal while the less able members flounder as a captive audience.

In this case, the group leader may assure equal opportunity for all participants and encourage members to express their ideas as freely as possible using the target language. In addition, since some students work harder in small group and finish quickly, the teacher has to join the weaker students as a group member for a time being and settle the problem.

Sometimes group work is considered as a time consuming for the time it takes during arranging the furniture and students introducing each other and returning to their former place. However, even if it wastes time for accomplishing the above-mentioned issues, students learn in-group work better than the lockstep; in lockstep, students have no time to participate in the target language and they cannot get time to learn from one another. Therefore, students who take part in-group activities do not waste time compared to lockstep.

\section{The Impact of Teachers' and teachers' Attitude towards Group Work Activities}

Attitudes could be viewed as a tendency to respond positively or negatively towards a certain thing, idea, person and situation. Hashemi (2005) defined attitudes towards the subject as the extent to which students accept the subject as well as their opinions towards it. The Longman Dictionary of Contemporary English (2001) defined attitudes as "opinions and feelings that you usually have about something". Chapman and McKnight (2004) define attitude as the way a person looks at things mentally; it represents the overall mood in which people interpret what a person says and does.

Attitude is, then, seen as a settled "behavior or manner of acting" reflecting individuals' feelings or opinions. Thus, attitudes could highly influence how individuals approach many situations in life, including group work activities. It is believed that individuals with positive attitudes usually progress more rapidly in group learning. Attitudes are closely related to our beliefs and are based upon experiences, thus, the researcher believes that effective language teaching approach can encourage students to be more positive towards the learning process in group work.

Teachers' attitudes are important for understanding and improving educational processes. They are closely linked to teachers' strategies for coping with challenges in their daily professional life and to their general wellbeing, and they shape students' learning environment and influence student motivation and achievement. Teachers' attitude can play an important role in teaching and learning process. According to Verma (2005) in current trends of language teaching, teachers have almost changed their role from being the controller of the class to facilitator. This implies that they accept students' mistakes in the language use as a necessary part of the language teaching and learning. They help and motivate students to use more and more language in their daily life, because learners learning outcomes are influenced by the interpretation of teachers' interpersonal behavior. If they believe that their teacher gives due attention for their learning outcome, understands their problems, they react positively and this factors contribute to their motivation level in the classroom.

Group work activity provides an opportunity for students to engage in peer-to-peer learning. Learning is enhanced when students are able to share and clarify their knowledge, and build creative problem solving capabilities (Johnson and Johnson, 2005). Working together productively can result in more favorable attitudes to learning and persistence within degrees (Scott-Lad and Chan, 2008; Springer, Stanne, and Donovan, 1999) and academics often favor group work for its anticipated reduction in marking loads.

Students' attitude plays an important role in language teaching-learning process. A learner's attitude to the group work will impact the learner outside the classroom. The study done by Burden (2004) cited in Hagose (2012), showed that a positive attitude would motivate learners to achieve their learning goals. In teaching-learning process, if a student is eager to learn in group this positive attitude is helpful for his/her study.

Student attitudes toward group learning are an important component of the educational process for at least two reasons. First, students' attitudes are hypothesized to reflect the quality of a student's learning experience. Consequently, knowing students' attitudes toward group work can facilitate the implementation of cooperative learning in classrooms. The way in which group learning is being implemented and the degree to which teachers persevere with this pedagogical approach may be enhanced by understanding the impact of student attitudes in this process.

A second reason why attitudes are important to the educational process is that student attitudes are hypothesized to influence group learning behaviors. It is possible that negative attitudes toward group work may expose group interactions and relationships, as well as student learning. Attitudes, once formed, influences how students think, feel, and behave. "Attitudes and beliefs are a subset of a group of constructs that name, define and describe the structure and content of mental states that are thought to drive a person's actions" (Rimm-Kaufman and Sawyer, 2004). The measurement of these student attitudes may yield important insights about how these attitudes enhance or hinder group work activities. Thus, a person who holds strong beliefs that positively valued outcomes will result from performing the behavior will have a positive attitude toward the behavior. Conversely, 
a person who holds strong beliefs that negatively valued outcomes will result from the behavior will have a negative attitude. Language learning can be affected by the attitude of people in teaching and learning process.

\section{The Teachers' and Students' Role in Group Work Activity \\ 8.1. The teachers' role in group work activity}

Role is a duty that a responsible person has to carry out. According to Wright 1987:2, role is an actor's part, or one's function, what a person is appointed or predictable to do. The role of the teacher in group activities is considerably different from the role that is expected of him in traditional classes. Teachers should encourage equal participation between group members to structure each activity that has different parts and sections to be performed by different group members (Richards and Rodgers, 2001). The tasks may require specific multiple abilities like: observation, manipulation, and assumption, hypothesizing and writing a report (Cohen, 1972). In the traditional way, the role of the teacher is lecturing, because he is expected of being a source of all knowledge. However, in communicative language teaching and group work in particular, the teacher is facilitator, organizer, guider and motivation reviver (Long and Porter, 1985).

Before the start of the group work activity, teachers should tell students what to do (the instructions and the tasks). They should decide the size of the group and group formation. They have to brief the roles of each group member and tell the time given for the task (Byrne, 1987; Harmer; 1999; Cohen; 1994). Teachers need to assign a role to group member and make explanations clear for all of the learners. In the other way, teachers should encourage students' for cooperation by assigning functionary roles such as a chairperson, secretary or reporter (Ur, 1981). Teachers can support balanced groups interactions by assigning roles to group members by reminding them the skills for cooperation. According to Jacobs and Ball (1996), structuring depends on students' group experience after students gain enough group experience they will work together without the teacher structuring task for them.

During the group work activity, the role of the teacher is to control, guide, check the activities of the learners and stop if time is up. After group work activity, the teacher should permit learners to report their works, persuade students to comment and ask forward specific and general feed back and tell their results if the task is graded (Brumfit 1984; Byrne 1987; Nunan 1989; Mulat 2007). Therefore, for effective consumption of group work teachers should perform or play their expected responsibility.

Teachers are like good midwives, empower and find ways to activate students for they know that learning requires active engagement between the subjects and object matter and know when to hang back and be silent, when to watch and wonder at what is taking place all around them. They can push and they can pull when necessary just like midwives but they know that they are not always called upon to perform. Sometimes the performance is and must be elsewhere.

Hill (1980:48) influentially describes the shared vulnerabilities when teachers and students climb together: The Teacher as mountaineer learns to connect. The guide rope links mountain climbers together so that they may assist one another in the ascent. The teacher makes a 'rope 'by using the oral and written contributions of the students, by forging interdisciplinary and interdisciplinary links where plausible, and by connecting the course material with the lives of students. The teachers' role in group work activity is not only guiding them, he can help them by showing different examples.

\subsection{The students' role in group work activity}

In order to accomplish group work activities, students need to interact or make a verbal exchange in the target language. In the process of interaction, they get experience to inclusive input, which refers to language features a bit beyond learners' current level of understanding (Krashen, 1985). This linguistic input has to be negotiated through such strategies, classification, confirmation, checking comprehension and repetition for mutual understanding to take place among the learners in doing the task (Nation 1975).

Learning in group work activity gives high responsibilities for learners to improve their communicative competence Nunan(1989:80) suggested, "Learners must take responsibility for their own learning by developing autonomy and skills in learning how to learn". Moreover, Cook (2001) stated that learning takes place in the learners' mind in ways that teachers cannot control. This is an indication that although teachers play their responsibility, unless students perform their responsibility, the goal of learning in groups cannot be achieved. Therefore, students should carry out their different responsibilities.

Before group work activity, students should be clear with the instruction and ready to participate actively in the group work activity (Nunan 1989; Ellis1995; Harmer, 2001). For the achievement of the designed work, students should introduce each other, select group leader and secretary.

According to Harmer (2001) during the group work activity, students are expected to play different responsibility such as, group leader, who is responsible for all the discussion in the group, keeping the group on task for each activity and ensuring everybody assumes his share of the work involved. In general, members in the group work activity have to contribute different roles to perform the task. According to Byrne (1987) and Smith (2008) stated that every team member should support the work of the team, contribute ideas about content and 
process and listen carefully to others.

In addition, members of the group could help to move the team to its goal in order to keep on the task and maintain a positive attitude. As Weimer (2002:214) successful students exhibit a combination of successful attitudes and behaviors as well as intellectual capacity. Members in a group: are responsible and active by involving in their studies, accept responsibility for their own education, and are active participants in the group. They have legitimate educational goals and are motivated by representing in terms of career aspirations and life's desires. They ask questions to provide the quickest route between ignorance and knowledge. They discuss about what they are learning and get to know something well enough that they can put into words and do not sit at the back and minimize classroom distractions that interfere with learning.

\section{Factors Affecting the Implementation of Group Work Activities}

Affect is the expression of one's attitude towards a certain thing, situation or experience. In English language study, affect is one's attitude, emotion, feeling and mood. The affective factors include motivation, self-esteem, selfconfidence and self-image (Zhu \&Zhou, 2012). However, the implementation of group work activities may be affected by many factors. These are: the teacher related factors, students related factors, the class size, and the physical environment, shortage of instructional materials, mother tongue interference, grouping factors and nature of the task.

\subsection{Teachers Related Factors}

According to Molalign (2011), factors like teachers' belief, attitude, professional experience, motivation, training, and teachers' understanding of innovation as the factors which affect the implementation of pedagogical innovations. The teacher must be well trained, must focus and monitor the educational process, be dedicated and respective to his or her students, and be inspirational. The teacher is also one of factor that affects the implementation of group work assignment in language learning. The well trained teacher who may perceive the important technique that helps to monitor educational process may affect group work assignment positively in language learning.

\subsection{Students Related Factors}

Students' knowledge of how group work activity is implemented and what is expected of them highly influence the application of group work activities. Darry and Terry (1993) stated that the importance of students' experience is a transformative rather than passive accumulation of knowledge. They notice that unless learners considered the implication of the ideas in their own lives and decide to the act know and believe in new ways, they are likely to adapt a passive acquaintance to the teachers' knowledge structure. Internal factors related with psycho-social aspects which influence students learning include: attitude, motivation, age, and previous language learning experience are common. All of these will combine to form each student's standard and the combination of individual standard will of course form the class standard.

Moreover, the student must have access, ability, interest, and value education (Palmer, 2007). As his view student by him/herself is one of the factors that affect his/her activities in language learning. If students have access to do activities or facilities which may help to practice, and students may be motivated to participate in the activities.

\subsection{Class Size}

It is not suitable to provide different group work activities having many students in overcrowded classroom. Bethel (2011) states that schools in many parts of Africa are composed of large number of students. Thus, giving enough attention and meeting the need of every different student, so as to engage actively in the learning process is difficult. For this reason, teachers attempt to, retain control and teach all the students all the same times by lecturing them. What may be said here is that, for proper implementation of group work activities, the number of student in the class should be optimum.

\subsection{Physical Environment}

A number of schools confirmed that the physical environment (class room arrangement, furniture arrangements, classroom appearance and lay out etc.) contribute a lot to promote cooperative learning (Leech and Wooster, 1986). A clean and well kept room with appropriate resource helps to establish a positive expectation towards an activity.

\subsection{Instructional Materials}

Instructional materials play a great role by giving opportunity to the learner to learn by themselves and enhance learners' participation through active engagement activities. According to Brown (1994), the roles of instructional materials are: ensure longer retention of the information gain, motivate the students to pay attention to the lesson, to help students to integrate prior experience with the pre set varying from abstract to concrete. However, in the instructions, lack of instructional materials may hinder implementation of group work activities 


\subsection{Mother Tongue Interference}

McDonough and Shaw (1993) revealed that in small group discussion, some or all of the students might use their first language than the second language. But it is very natural to have such a situation and to use in time of frustration. However, to reduce such problems, the task should be easy and be designed to participate students using the targeted language. Moreover, the use of L1 may lead to the productive use of the targeted language if handled with care (Wilkins, 1974).

\subsection{Grouping Factors}

The other problem is the challenge of grouping. If their teacher groups students, they may conflict each other. In addition, if they are allowed to form groups by themselves, they talk/play other issues than the task, and shy students are at disadvantage. Therefore, they consider group work as a play than working (Hare, 1994). However, if group work is properly organized and handled and if students properly use or perform their expected roles, the problems will be reduced and it will pave the way for a good end in language learning.

\subsection{Nature of the Task}

According to Ur (1981) for tasks to be done through verbal interaction, point and purpose seems to be necessary so that they will have power to force interactions. After preparing necessary conditions, the teacher has to set tasks and materials for the groups. This is the stage where groups are actively engaged in their work to solve tasks in an effort to achieve high quality of group products.

The group members are expected to collaborate with each other and coordinate their offers using their target language English. The activities should be intrinsically interesting and challenging to encourage verbal interactions in line with the goal of group work (Nation, 1994). In addition, Nunan (1989) stated that teacher has to play three main roles and acting as facilitator, participant and observer. Parallel to this the students are taking greater initiative. The point is that learning is something only the learners can do for themselves.

Regarding how to overcome problems of low interactions resulting from the nature of the task Ur (1981) recommends selection of activities to be simple, interesting, challenging and encouraging for interaction. It is also necessary to adopt activities to the level, interest, age and background of the learners so as to solve the problems.

\subsection{Academic Status and Language Proficiency of the students}

In group work activities some members seems to be more influential than others even though they are equal in every respect. According to Cohen (1972) status is an agreed up on social ranking in which every body prefers to have a high rank than a low rank with in a given status order. To have equal benefit in the group, members of a group should have equal chance to talk, interact and contribute. Status difference inhibits the normal pattern of interaction and meaning negotiation. High status is often associated with competence. Some high status students tend to participate more actively than low status members are.

In relation to this Cohen (1972:28) stated that Status characteristics are general expectations for competence. High status individuals are expected to be more competent than low status individuals are across a wide range of tasks that are viewed as important. If a teacher assigns a task to a group of students, some of whom are higher and some lower on any of the status characteristics, which come in to play.

Academic status is a factor that affects the implementation of group work activity. According to Cohen(1972) a student who is seen as best in reading is likely to dominate group activity, on the other hand a student who is seen as poor in reading is very likely to be relatively inactive in other tasks. Academic status also creates a problem when it spreads to a wide range of new activities, which do not require the skill that has made up the status.

Language proficiency is also one of the problems that impede groups to accomplish their task. According to Ellis (1994) high proficient students are likely to participate in foreign language more actively than less proficient ones. In addition to this, Girma (2005:117) stated that, because of students very little proficiency, they do not participate when asked to work in groups. When they are asked, they say they do not understand. This is because the student's proficiency in English is not good enough to enable them to use the language or to carry out a group work activities. Students resist to use English or to work in groups is due to their lack of proficiency.

Similarly, Jacobs and Ratmandia (1996) stated that, lack of language proficiency is a reason for student's failure to do well in groups. Most important, high student's motivation and high self-confidence, which are vehicles for any learning, on the other hand, low motivation and low self-confidence makes learning difficult.

When the gap between high and low achievers is meaningful and the atmosphere is competitive, the impact of language proficiency becomes harmful and result two disadvantages. Firstly, the dominance of few fluent speakers make the less proficient learners to give up the task .Secondly, they may return to use their mother tongue as an alternative to succeed. The main challenges often mentioned in using group work activity, according to Davies (1980) and Harmer (1991) are the desire to use the first language, which according to Ur (1981) when students have a threshold of the second language proficiency requires treatment for it counters the goal of group work. Harmer (1991) believes that this could be due to inability or unwillingness, which proposes convincing 
students to use the target language or doing controlled activities until they are ready for communicative activities.

\section{Concept of Speaking in group work activities}

Speaking is the ability to communicate meaning successfully with partners when there are problems in communication process, has improved (Dornyei and Thurell, 1991). Also it is a way of verbalizing what you think and believe (Micula, 1999). He also stated that speaking is designed to provide you with the speech communication skill that is essential in talking with one person, in a group or in front of an audience.

Saville (2006) stated that the best learning occurs when learners feel comfortable and enjoy the classroom activities. Therefore, enjoying and participating the classroom activities in group without any anxiety their need to speak English higher and higher. Fakhar (2012) defined speaking is described as interactive process of constructing meaning that involves producing and receiving and processing information. Speaking depends on the context or situation; context includes the physical environment (McDonough et al, 1993:132). Moreover, Speaking as mutual attempts of two interlocutors to agree on a meaning in situations where the requisite meaning structures.

\section{Activities Used to Teach Speaking in group}

Oral expression activities are conducted with group work to stimulate learners' interest and to defeat their feeling of shyness and fear, as they are helpful in giving each learner, especially for overcrowded classes, the chance to participate within the group (Putnam, 1997). They are conducted through separating the class into groups, with a chief for each group and then give them the task.

After a limited period of time, all learners meet again and debate what they found as results. The teacher organizes his learners in the classroom according to two shapes, the first one is that learners sit roundly to see each other and to ease their contributions; and the second one is that learners are put into a group of two learners, and ask them to converse between each other one asks and the other one replies (Byrne, 1986). As he can help students with vocabulary and expressions necessary for the exercises as well as offering students the chance to contribute orally through paying the students' attention to ask questions that need long answers, as he must correct just students' errors that cause misunderstanding among them.

\section{Functions of Speaking in Group Work Activities}

Numerous attempts have been made to categorize the functions of speaking in human interaction. Brown and Yule (1983) state a useful distinction between the interactional functions of speaking, in which it serves to establish and maintain social relations and the transactional functions, which focus on the exchange of information in workshops with teachers and in designing my own materials. Jones (1996) pointed out that talk as interaction refers to what we normally mean by "conversation" and describes interaction that primarily social function. When people meet, they exchange greeting, engage in small talk, recount recent experiences, and so on, because they wish to be friendly and to establish a comfortable zone of interaction with others. The focus is more on the speakers and how they wish to present themselves to each other that on the message.

Such exchange may be either casual or more formal, depend on the circumstances, and their nature has been well described by Brown and Yule (1983). There are different functions of speaking explained in this section, for instance, use of interactional function, exchange of information, conversation that refer talk as interaction. With this regard, the researcher intended to investigate whether English language teachers use of group work activities to enhance learners' speaking skill.

\section{REFERENCES}

Adams, D. and Hamm, M. (1990). Cooperative Learning: Critical Thinking and Collaboration Across the Curriculum. Spring field, IL: Charless C. Tomas.

Artz, A. and Newman, C. (1990). Cooperative Learning. Mathematics Teachers, vol.83, No 448-449.

Badache, L. (2011). The Benefits of Group Work. The Social Science and Human Journal. Retrieved from http:/ respository. Yu. Edu. Jo/handle/12345678/449014 .

Bekele, B. (2011). Practice and Perception of Bulbula School Community towards the Implimentation of Active Learning in Teaching English: Bulbula Secondary School in Focus. MA Thesis. Addis Ababa: Addis Ababa University.

Birega, M. (2011). Factors that Hinder the Implementation of Communicative Language Teaching: Preparatory Shool in Focus. MA Thesis. Addis Ababa Addis: Ababa University.

Bloxham, S. and Health field, M. (1994). Marking Changes: Innovation in Design an Assessment of a Postgraduate Diploma in Youth and Community Work. In Gibbs, G. Improving Students Learning: Theory and Practice. Oxpord: OCSD.

Borich, G. (2007). Cooprative Learning. University of Virginia: Pearson Merrill/Prentice-Hall. Brown, G. and George, Y. (1983). Teaching the Spoken Language. Cambridge: Cambridge University Press. 
Brown, A. (1994). Group work $3^{\text {rd }}$ Edition Great Yarmouth. Ashagate publishing.

Brown, H. (1994). Principle of Foreign Language Teaching. Cambridge: Cambridge University Press.

Brown, H. (1987). Principle of Language Teaching. New Jersey: Prentice Hall.

Brown, H. (1994). Teaching by Principle: An Interactive Approach to Language Pedagogy. New Jersey: Prentice Hall Regent.

Brown, H. (2001). Teaching by Principle. New York: Edition Wisely Longman, Inc.

Brumfit, C. (1984). Communicative Methodology in Language Teaching. Cambridge: Cambridge University Press.

Burdett, J. and Hastie, B. (2009). Predicting Satisfaction with Group Assignment. Journal of University Teaching and Learning Practice, vol.6, No.1, pp. 61-70.

Byren, D. (1987). Techniques for Classroom Interaction. London: Longman.

Callahan, H. and Clark, L. (1988). Teaching in the Middle and Secondary School. New York: Macmillan Publishing Company.

Chapman, N. and McKnight, W. (2004). Attitude. Your most Price Possession. India: Crisp Publications, Inc.

Chirac, E. and Frykedal, K. (2001). Management of Group Work as a Classroom Activity. World Journal of Education, vol.1, No. 2, p.3.

Cohen, E. (1994). Collaborative Learning: Higher Education, Interdependence, and the Authority of Knowledge. Baltimore: John Hopkins University Press.

Cohen, E. (1972). Designing Group Work: Strategies for the Hetrogeneous Classroom. New York: Teachers College Press.

Cook, V. (2001). Second Language Learning and Language and Language Teaching. (3 ${ }^{\text {rd }}$ ed.) New York: Hodder Arnold.

Crandall, J. (1999). Cooperative Language Learning and Affective Factors. In Arnold, J (Eds.) Affecting Language Learning. Cambridge: Cambridge University Press.

Creswell, J. (2012). Educational Research: Planning, Conducting and Evaluating Quantitative and Qualitative Research. $\left(4^{\text {th }}\right.$. ed).. Boston: Pearson Education INC.

Doff, A. (1991). Teaching English. A Traning Course for Teachers. New York: Cambridge University Press

Dornyei, Z. and Thurrell, S. (1991). Strategies Competence and how to Teach it. ELT Journal, vol.45, No.1, p. $16-23$.

English, L. (2001). Pearson Educational Limited, Edinburgh Gate,. Harlow Esses CM 20 JE UK.

Exley, K and Dennick R. (2004). Small Group Teaching. Tutorial, Seminar, beyond. London: Rutledge.

Fakhar, N. (2012). Concept of Speaking and Listening Skills: Language Skill and Communication Abilities.

Falchikou, N. (2005). Improving Assessment through Student Involvement. London: Rout ledge Flamer.

Forsyth, D. (2006). Group Dynamics ( $4^{\text {th }} E d$ ). Thomson: Wadsworth Publishing.

Freeman, D. (2000). Techniques and Principles in Language Teaching. New York: Oxford University Press.

Gullies, R. (2003). Structuring Cooperative Group Work in Classrooms. International Journal of Educational Development, vol. 39, No.2, p. 35-49.

Hagos, H. (2012). The Major Callenges of Implementing Active Learning in EFL Classes of Wolaita Sodo University. MA Thesis, Addis Ababa: Addis Ababa University.

Hansen, R. (2006). Bebefits and Problems with Students' Teams. Suggests for Improving Team Projects, Journal of Education for Bussiness, Vol.82, no.1, p.11-19.

Hare, A. (1994). Group Size and Consensus. London: SAGE Publications Ltd.

Harmer, J. (1991). The Practice of English Language Teaching. New York: Longman: UK. Ltd.

Harmer, J. (2003). The Practice of English Language Teaching. Cambridge: Pearson Educational Publishing.

Hashemi, H. (2005). The Efectiveness of a Proposed Program for Teaching Arab language in Achievement and Attitude Non-native Speakers in Oman. PhD. Thesis. Cairo University.

Hill, F. (1980). Learning Through Discussion. London: Longman: SAGE Publications.

Johnson, D. and Johnson, R. (1990). Social Skills for Successful Group Work. Educational Leadership, Vol.47, no.4, p. 29-33.

Jacobs, M. and Ball, J. (1996). An Investigation of the Structure of Group Activities in ELT Course Books. ELT Journal , 50.2, pp. 99-107.

Johnson, D. and Johnson, R. (1991). Learning Together and Alone: Cooperative, Cometitive and Individualistic Learning ( $3^{\text {rd }}$ Ed.). Needham Height, MA. Allyn and Bacon.

Johnson, D., Johnson, R. and Holubec, E. (1994). The New Circle of Learning: Cooperation in the Classroom and School. Association for Supervision and Curriculum Development.

Jones, P. (1996). Planning an Oral Language Program. In Pauline (ed.), Taking to Learn. Melbourne: PETA, p. $12-26$.

Karmasch, C. (1992). Interactive Dicourse on Small and Large Groups. In W. River (Ed), Interactive Language Teaching New York: Cambridge Press University, p.17-30.

Kefale, Y. (2015). Problems Affecting the Implementation og Group Learning. Premary School in Focus. 
Unpublised MA thesis. Addis Ababa: Addis Ababa University.

Konopka, G. (1963). Social Group Work: Helping Process Englewood Cliffs, N.J. Prentice Hall.

Krashen, S. (1985). The Input Hypothesis: Issues and Implications. London: Longman.

Kumar, R. (1996). Research Methodology: Step by Step Guide for Beginners. London Sage Publication. University press. March 9th, 2008.

Kutnick, P. (2006). Improving the Effects of Group Work in Classrooms with Young School-aged Children. Facilitating Attinment, Interaction and Classroom Activity. Learning and Instruction, vol.18, no.1, p. 83-95.

Lejk, M. (1999). Group Assignment in Systems, Analysis and Design. A Comparision of the Performance of Streamed and Mixed-Ability Groups, Assessment and Evaluation in Higher Education, vol. 24, no.1, p. 5-14.

Long, M. (1995). Group Work Inter Language Talk and Second Language Acquisition. TESOL Quarterly, vol.19, no.2, p. 207-210.

Lotan, R. (2004). Stepping in to Group Work. New York: State University New York Press.

McDonough, J. and Shaw. (1993). Materials and Methods in English Language Teaching. A Teacher's Guide Oxford University Press.

McDonough, K. (2004). Learner-learner Interaction during Pair and Small Group Activities in a Thai EFL Context. System, vol.32, no.2, p.207-224.

Michael, L. (1985). Practical Techniques for Language Teaching. London: Language Teaching Publication.

Ministry of Education. (1994). "New English for Ethiopia” Text Books. Addis Ababa,

Ethiopia.

Mitchel, T. and Silver, W. (1990). Individual and Group Goals when Workers are Interdependent: Effect on Task Strategies and Performance. Journal of Applied Psychology, vol.75, p.185-193.

Negesse, F. (2002). The Organization of Group Work in Spoken English II Classes. Adama and Jimma Teachers Collage in Focus. MA Thesis. Addis Ababa: Addis Ababa University.

Nair, G. and Alwee, U. (2012). Group Work in Secondary ESL Classroom. Asian Social Science, vol.8, no.10, p. 3-7.

Nation, P. (1994). Group Work and Language Learning. English Teaching Forum, vol.26, no.4, p.161-169.

Ngoh, G. (1991). Small Group Work in the Classroom. Guidelines, vol.13, p.12.

Nunan, D. (1989). Research Methods in Language Learning. Cambridge: Cambridge University Press.

Nuna, D. (1987). Designing Tasks for the Communicative Classroom. Cambridge: Cambridge University Press.

Nunan, D. (1992 ). Collaborative Language Learning and Teaching. Cambridge: University Press.

Nunan, D. (1999). Second Language Teaching and Learning. USA: Heinle and Heinle Publisher.

Olsen, R. and Kaan, S. (1992). About Cooperative Lerning. In Kessler, C. (Ed). Cooperative Learning. A Teacher's Resource Book. Enlgewood Cliffs. New Jersely: Prentice Hall.

Onwegbuzie, A. and Leech. N (2004). Linking Research Questions to Mix Method Data Analysis Procedure. The qualitative report, vol.11, no.3, p.474-496.

Palmer, D. (2007). What is the Best Way to Motivate Students. The Journal of Australian Teachers Association, vol.53, no.1, p.38-42.

Patton, M. (1990). Qualitative Education and Research Method (2 ${ }^{\text {nd }}$ Ed). London: Sage Publications.

Petty, G. (2001). Teaching Today. UK: Nelson Thrones.

Reynold, S. (1994). Group Work in Education and Training. London: Longman.

Richards, J. and Rodgers,T. (1986). Approaches and Methods in Language Teaching. Cambridge: Cambridge Universty Press.

Richard, J. and Rodgers, T. (2004). Approaches and Methods in Language Teaching (2 ${ }^{\text {nd }}$ ed). Cambridge, UK: Cambridge University Press.

Rimm-Kaufman, S. and Sawyer, B. (2004). Primary Grade Teachers' Self-efficacy Belief, Attitudes toward Teaching and Discipline and Teaching Practice Priorities in Relation to the Responsive Classroom Approach. The Elementary School Journal, vol.104, no.321-341.

Saville-Trolke, M. (2006). Introducing Second Language Acquisition. Cambridge: Cambridge University Press.

Scott, V. and De la Fuente, M. (2008). What is Problem? L2 Learners' use of L1 during Consciousness-raising from Focused Tasks. Modern Language Journal, vol.92, no.1, p. 100-113.

Scrivener, J. (2011). Learning Teaching: The Essential Guide to English Language Teaching (3 ${ }^{\text {rd }}$ ed.). Oxford: Macmillan Pubilsher.

Seliger, H. and E. Shohamy. (1989). Second Language Research Method: Oxford University Press. Retrieved 12 , 03, 2012, from http://www.tc.umn.edu.

Seliger, H. and Shohamy, E. (1989). Second Language Research Methods. Oxford: Oxford University press.

Sharama, R. (2000). Fundamental of Educational Research. Mcerut: Inter Publishing House.

Spiegel, D. (2005). Classrooom Discussion. USA: Scholatic inc.

Springer, L. Stanne, M. And Donovan, S. (1999). Effects of Small Group Learning on Undergraduates in Science, Mathematics, Engineering and Technology a Meta-analysis. Review of Educational Research, vol.69, p. 21- 
48.

Tuan, L. and Nhu, N. (2010). Theoretical Review on Oral Interaction in EFL Classrooms. Students in Literature and Language, vol.1, no.4, p.28- 48.

Ur, P. (1996). A Course in Language Teaching: Practice Theory. Cambridge: Cambridge University Press.

Ur, P. (1981). Discussion That Work: Task Centered Fluency Practice. Cambridge: Cambridge University Press.

Verma, M. (2005). Learners' Attitude and Its Impact on Language Learning. India: Institute of Engineering and Technology.

Wichadee, S. (2007). The Effect of Coopretive Learning on English Reading Skills and Attitudes of the First Year Students at Bngkok University. Presented at the Conference of Languages for Specific Purposes in Higher Education Searching for Common Solution organized by Brno University of Technology, Czech Republic. November, 29-30-2007.

Wilkins, D. (1974). Second Language Learning and Teaching. London: Edward Arnold Ltd.

Yada,Y. and Martin, B. (2009). Effective Activities Involving Pair and Group Gork. Oxford: Oxford University.

Zhu, B. and Zhou, Y. (2012). A Study on Students' Affective Factors in Junior High Scool English Teaching. Foreign Language Schoo, Zhejian Ocean University, Chinal, Vol.5 no.7. 